\title{
Upaya Meningkatkan Prestasi Belajar IPS Melalui Penggunaan Model Pembelajaran Tipe Cooperative Integrated Reading and Compotition (CIRC)
}

\author{
Ni Made Terima \\ SD Negeri 4 Tulikup \\ e-mail: mdterima@gmail.com
}

\begin{abstract}
Abstrak
Penelitian ini dilaksanakan di SD Negeri 4 Tulikup di kelas III Semester II Tahun Pelajaran 2017/2018 yang kemampuan siswanya untuk mata pelajaran IPS masih rendah. Tujuan penulisan penelitian tindakan kelas ini adalah untuk mengetahui apakah penggunaan Model Pembelajaran Tipe Cooperative Integrated Reading and Compotition (CIRC) dapat meningkatkan prestasi belajar siswa. Metode pengumpulan datanya adalah tes prestasi belajar. Metode analisis datanya adalah deskriptif. Hasil yang diperoleh dari penelitian ini adalah penggunaan Model Pembelajaran Tipe Cooperative Integrated Reading and Compotition (CIRC) dapat meningkatkan prestasi belajar siswa. Ini terbukti dari hasil yang diperoleh pada pada awalnya 58,33 setelah diberikan tindakan pada siklus I meningkat menjadi 63,54 dan pada siklus II meningkat lagi menjadi 76,25. Kesimpulan yang diperoleh dari penelitian ini adalah penggunaan Model Pembelajaran Tipe Cooperative Integrated Reading and Compotition (CIRC) dapat meningkatkan prestasi belajar IPS siswa kelas III SD Negeri 4 Tulikup.
\end{abstract}

Kata Kunci: Model Pembelajaran Tipe Cooperative Integrated Reading and Compotition (CIRC), Prestasi Belajar.

\begin{abstract}
This research was carried out in SD Negeri 4 Tulikup in class III of Semester II in the 2017/2018 Academic Year whose students' abilities for social studies subjects were still low. The purpose of writing this class action research is to find out whether the use of Cooperative Integrated Reading and Compotition Type Learning Model (CIRC) can improve student learning achievement. The data collection method is a learning achievement test. The data analysis method is descriptive. The results obtained from this study are the use of Cooperative Integrated Reading and Compotition Type Learning Model (CIRC) can improve student learning achievement. This is evident from the results obtained at the beginning of 58.33 after being given the action in the first cycle increased to 63.54 and in the second cycle increased again to 76.25. The conclusion obtained from this study is that the use of Cooperative Integrated Reading and Compotition Type Learning Model (CIRC) can improve social studies learning achievement of grade III students at SD Negeri 4 Tulikup.
\end{abstract}

Keywords: Cooperative Integrated Reading Type and Compotition Learning Model (CIRC), Learning Achievement 


\section{Pendahuluan}

Pembangunan nasional dilaksanakan dalam rangka membangun manusia Indonesia seutuhnya dan pembangunan masyarakat Indonesia seluruhnya. Hal ini berarti bahwa pembangunan itu tidak hanya mengejar lahiriah seperti sandang, pangan, perumahan, kesehatan, dan sebagainya atau kepuasan batiniah saja seperti pendidikan, rasa aman, bebas mengeluarkan pendapat dan sebagainya, melainkan juga keselarasan, keserasian, dan keseimbangan antara keduanya.

Dalam rangka menciptakan manusia seutuhnya maka pembangunan pendidikan merupakan bidang yang penting untuk mendapatkan prioritas. Hubungan dengan hal tersebut, maka pendidikan memerlukan konsep yang baku sehingga pelaksanaan sistem pendidikan dapat menciptakan manusia yang siap pakai.

Tujuan pendidikan nasional berdasarkan UU sistem penddidikan nasional tahun 2003 dinayatakan bahwa Pendidikan Nasional berfungsi mengembangkan kemampuan dan membentuk watak serta peradaban bangsa yang bermartabat dan dalam rangka mencerdaskan kehidupan bangsa, bertujuan untuk berkembangnya potensi peserta didik agar menjadi manusia yang beriman dan bertakwa kepada Tuhan Yang Maha Esa, berakhlak mulia, sehat, berilmu, cakap, kreatif, mandiri, dan menjadi warga negara yang demokratis serta bertanggung jawab (SPN, 2003: 7).

Dikatakan bahwa pendidikan itu berlangsung seumur hidup dan dilaksanakan dalam keluarga, sekolah dan masyarakat, karena itu pendidikan merupakan tanggung jawab bersama antara keluarga, masyarakat, dan pemerintah. Dengan demikian unsur keluarga merupakan hal yang penting sebelum mengarah lebih lanjut pada sekolah dan masyarakat. Mengingat pentingnya peranan keluarga itu terhadap pendidikan terutama terhadap anak-anaknya. Peranan orang tua yang langsung terhadap anak-anaknya juga adalah mendidik untuk menciptakan ilmu yang berguna baik melalui sekolah yang berlangsung secara terus menerus maupun di lingkungan masyarakat di mana ia berada. Hal ini berarti penyediaan materi dan spirit anak-anaknya turut menentukan, termasuk mengawasi hal-hal yang tidak diinginkan agar tujuan mewujudkan anak yang soleh dapat tercapai.

Guru wajib menciptakan suasana pendidikan yang bermakna, menyenangan, kreatif, dinamis, dialogis, berkomitmen meningkatkan mutu pendidikan, memberi tauladan, menjaga nama baik lembaga. Guru berperan untuk mampu melakukan interaksi, pengasuhan, mengatur tekanan, memberi fasilitas, perencanaan, pengayaan, menangani masalah, membimbing dan memelihara. Dengan guru memahami tugas-tugas tersebut dan memahami apa yang mesti dilakukan tentu saja kondisi yang diharapkan dalam pembelajaran di sekolah dasar akan dapat terlaksana dengan baik. Selain memahami hal-hal tersebut, guru juga harus mengetahui faktorfaktor yang mempengaruhi pertumbuhan anak (Yamin dan Sanan (2013: 30-32).

Dari semua kutipan di atas jelaslah kondisi yang diharapkan dalam pembelajaran bagi anak-anak SD, untuk itu guru harus mampu melaksanakannya agar peningkatan mutu pendidikan dapat dicapai sesuai harapan. Kenyataan yang ada di lapangan ternyata tidak sesuai dengan semua harapan tadi, ini terlihat pada data awal penilaian kemampuan berbahasa anak SD Negeri 4 Tulikup kelas III pada semester II tahun pelajaran 2017/2018 yang diukur menggunakan kriteria penilaian setelah dilakukan Model Pembelajaran Tipe Cooperative Integrated Reading and Compotition (CIRC). Mengacu kriteria penilaian yang ditetapkan, kemampuan mereka baru mencapai rata-rata 58,33. Menurut Jenisa (2016) Model Pembelajaran Cooperative Integrated Reading and Composition (CIRC) adalah jenis model pembelajaran kooperatif. Pembelajaran kooperatif tipe CIRC ini pertama kali dikembangkan oleh Robert E. Slavin. Berdasarkan beberapa penelitian, model pembelajaran kooperatif Ini dapat memberikan pembelajaran yang lebih banyak dari pada model-model lainnya. Hal ini dikarenakan pembelajaran kooperatif dibangun atas dua perspektif teori utama yaitu perspektif motivasi dan perspektif kognitif. Menurut llham (2016) Pada dasarnya model pembelajaran kooperatif tipe CIRC me-ngandung pengertian sebagai suatu sikap atau perilaku bersama dalam bekerja atau membantu di antara sesama secara teratur. Keberhasilan kerja sa-ngat dipengaruhi oleh keterlibatan dari setiap anggota kelompok itu sendiri. Anggota kelompok tersebut hendaknya dalam bekerja sama saling toleransi, percaya diri, santun, dan bersyukur dalam me-mecahkan masalah dikelompoknya. Menurut Ariyandika (2017) Dengan model CIRC ini diharapkan dapat membantu siswa dalam kemampuan pemecahan masalah matematis siswa memahami dan menyelesaikan soal uraian atau soal cerita. Dalam model pembelajaran CIRC ini Siswa dituntut untuk aktif dalam proses pembelajaran di kelas sehingga aktivitas siswa lebih menonjol, tercipta suasana nyaman dan menyenangkan untuk belajar. Hal tersebut 
diharapkan mampu untuk membantu siswa dalam mengembangkan kemampuan pemecahan masalah matematis siswa. Menurut Aprilianty (2016) pembelajaran kooperatif tipe CIRC peneliti pilih karena merupakan salah satu model pembelajaran kooperatif yang memanfaatkan kerjasama dalam kelompok untuk membantu siswa memahami materi pembelajaran melalui bahan bacaan, wacana, atau kliping dengan cara membaca, menganalisis, memecahkan masalah, membuat laporan dan presentasi hasil kerja kelompoknya. Menurut Sukiastini (2013) Model pembelajaran Cooperative Integrated Reading and Composition (CIRC) merupakan desain pembelajaran yang dapat memenuhi semua syarat tersebut, model pembelajaran Cooperative Integrated Reading and Composition (CIRC) mampu meningkatkan interaksi antarsiswa, motivasi belajar siswa dan meningkatkan tanggung jawab siswa. Kegiatan pokok dalam CIRC untuk menyelesaikan soal pemecahan masalah meliputi rangkaian kegiatan bersama yang spesifik, yaitu: (1) Salah satu anggota atau beberapa kelompok membaca soal, (2) Membuat prediksi atau menafsirkan isi soal pemecahan masalah, termasuk menuliskan apa yang diketahui, apa yang ditanyakan dan memisalkan yang ditanyakan dengan suatu variabel, (3) Saling membuat ikhtisar/rencana penyelesaian soal pemecahan masalah, (4) Menuliskan penyelesaian soal pemecahan masalah secara urut, dan (5) Saling merevisi dan mengedit pekerjaan/penyelesaian. Proses memecahkan masalah yang dialami siswa akan membangitkan aktivitas siswa dan nantinya juga akan dapat mengembangkan keterampilan berpikir kreatif siswa secara berkesinambungan. Sehingga, model pembelajaran kooperatif CIRC dapat dikatan memberi kontribusi yang sangat positif dan baik dalam memecahkan masalah dan mampu mengembangkan keterampilan berpikir kreatif siswa.

Kondisi tersebut jika dibiarkan, dapat memunculkan masalah baru yang lebih serius dan dikhawatirkan dapat mengganggu perkembangan kemampuan anak secara menyeluruh. Sehingga sebagai seorang guru harus berupaya untuk memecahkan masalah yang ada. Untuk hal tersebut peneliti mencoba mengintensifkan penggunaan Model Pembelajaran Tipe Cooperative Integrated Reading and Compotition (CIRC) untuk mengupayakan peningkatan prestasi belajar anak.

\section{Metode}

Penelitian yang dilakukan termasuk penelitian tindakan.Oleh karenanya, rancangan yang khusus untuk sebuah penelitian tindakan sangat diperlukan.Penelitian tindakan didasarkan pada filosofi bahwa setiap manusia tidak suka atas hal-hal yang statis, tetapi selalu menginginkan sesuatu yang lebih baik.Peningkatan diri untuk hal yang lebih baik ini dilakukan terus menerus sampai tujuan tercapai (Arikunto, Suhardjono, Supardi, 2006: 67).Dalam melaksanakan penelitian, rancangan merupakan hal yang sangat penting untuk disampaikan. Tanpa rancangan, bisa saja alur penelitian akan ngawur dalam pelaksanaannya.

Untuk penelitian ini penulis memilih rancangan penelitian tindakan yang disampaikan oleh Mc. Kernan seperti terlihat pada gambar berikut.

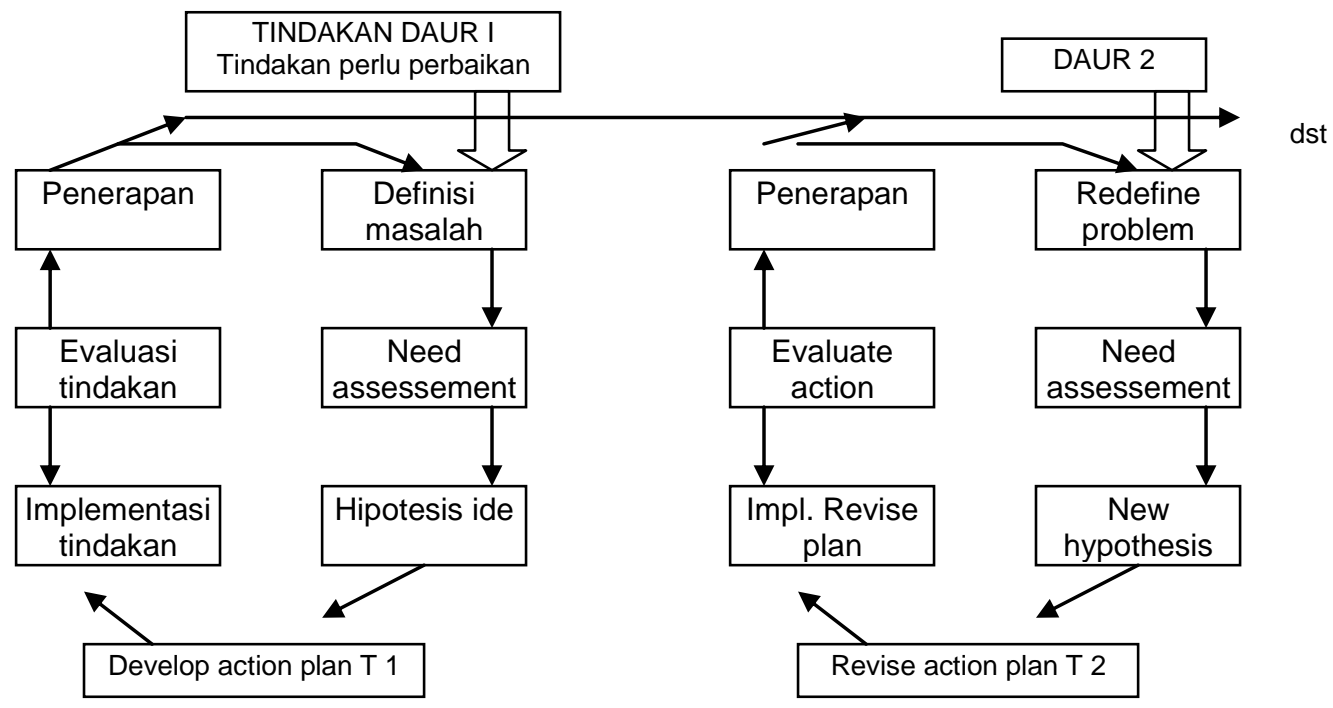

Gambar 1. Penelitian Tindakan Model Mc. Kernan, 1991 (dalam Sukidin, Basrowi, Suranto, 2002: 54) 
Prosedur:

1. Tindakan daur I: mulai dari definisi masalah, berlanjut ke assessment yang disiapkan, berlanjut ke rumusan hipotesis, berlanjut ke pengembangan untuk tindakan I, lalu implementasi tindakan, evaluasi tindakan berlanjut ke penerapan selanjutnya.

2. Tindakan daur II: mulai dari menentukan kembali masalah yang ada, berlanjut ke assessment yang disiapkan, terus ke pemikiran terhadap munculnya hipotesis yang baru, perbaikan tindakan pada rencana ke 2 , pelaksanaan tindakan, evaluasi terhadap semua pelaksanaan dan penerapan.

Prosedur yang dilakukan dengan model ini adalah pada awalnya menemukan kekurangan-kekurangan yang ada, setelah dianalisis ternyata kemampuan anak dalam pelajaran Bahasa Indonesia masih rendah sehingga dibuat perencanaan, dilanjutkan dengan langkah-langkah tindakan yaitu melatih terus sesuai kaidah pembelajaran di SD karena penilaian terhadap kemajuan anak harus diupayakan berkesinambungan, begitu juga penilaiannya. Lara Fridani, dkk (2009: 6.6) mengatakan bahwa assesment perkembangan anak dilaksanakan secara terus menerus dan berkesinambungan. Setelah langkah tindakan dimonitor berserta efeknya serta kegagalannya bisa ditemukan, dibuat revisi untuk perencanaan selanjutnya. Demikian terus bergulir sampai penelitian berhasil sesuai indikator yang diusulkan. Untuk indikator tersebut ada di Bab III ini dibagian yang paling akhir.

\section{Hasil dan Pembahasan}

Dalam pembelajaran CIRC atau pembelajaran terpadu setiap siswa bertanggung jawab terhadap tugas kelompok. Setiap anggota kelompok saling mengeluarkan ide-ide untuk memahami suatu konsep dan menyelesaikan tugas (task), sehingga terbentuk pemahaman yang dan pengalaman belajar yang lama. Model pembelajaran ini terus mengalami perkembangan mulai dari tingkat Sekolah Dasar (SD) hingga sekolah menengah. Proses pembelajaran ini mendidik siswa berinteraksi sosial dengan lingkungan.

Prinsip belajar terpadu ini sejalan dengan empat pilar pendidikan yang digariskan UNESCO dalam kegiatan pembelajaran. Empat pilar itu adalah "belajar untuk mengetahui (learning to know), belajar untuk berbuat (learning to do), belajar untuk menjadi diri sendiri (learning to be), dan belajar hidup dalam kebersamaan (Learning to live together), (Depdiknas, 2002).

Deskripsi awal telah menunjukkan rendahnya prestasi belajar siswa yang diakibatkan oleh faktor-faktor luar dan faktor-faktor dari dalam diri guru sendiri. Faktor-faktor tersebut telah dipahami betul dan pelan-pelan diperbaiki agar proses pembelajaran tidak dipengaruhi oleh faktor-faktor tersebut dengan cara membuat perencanaan yang lebih baik pada siklus berikutnya. Dari faktor siswa tentang kurangnya motivasi orang tua dalam mengarahkan anakanak mereka untuk mau giat belajar dilakukan dengan memberi pengarahan lewat penyampaian yang dilakukan kepala sekolah terhadap orang tua siswa.

Dari hail pengamatan yang telah dilakukan pada siklus I ini dalam upaya pembenahan proses pembelajaran di kelas dapat disampaikan bahwa ada kelebihan-kelebihan yaitu peneliti telah membuat perencanaan yang matang, dengan terlebih dahulu membaca teori yang ada, dalam pelaksanaan pembelajaran peneliti sudah berpakaian rapi, menggunakan bahasa yang santun, menuntun siswa dengan baik. Hal ini menimbulkan nterpretasi bahwa perjalanan penelitian sudah cukup baik. Kelemahan yang disampaikan perlu diberikan analisis yaitu penggunaan waktu yang belum efektif, konstruksi, kontribusi siswa belum maksimal, fakta ini akan dijadikan acuan kebenaran data, validasi internal validitas eksternal berupa penggunaan teori-teori yang mendukung dan reliabilitas data penelitian ini dapat penulis yakini karena hal itu merupakan ketepatan peneliti memilih instrumen. Faktor-faktor yang berpengaruh belum maksimalnya pembelajaran pada siklus I ini adalah karena peneliti baru satu kali mencoba model ini. Cara pemecahan masalahnya adalah penyiapan RPP yang lebih baik, lebih berkualitas, meminta pendapat teman sejawat untuk memperoleh tambahan pengalaman, gambaran-gambaran.

Dari gambaran pelaksanaan yang telah dilakukan ternyata hasil yang diperoleh pada siklus I ini sudah lebih baik dari hasil awal yang baru mencapai nilai rata-rata 58,33 dengan ketuntasan belajar $45.83 \%$. Pada siklus I ini sudah mencapai peningkatan sedikit lebih tinggi yaitu dengan rata-rata 63,54 dan ketuntasan belajar $62,50 \%$. Namun hasil tersebut belum maksimal karena tuntutan indikator keberhasilan penelitian adalah agar peserta didik mampu memperoleh rata-rata 75,00. Oleh karenanya penelitian ini masih perlu untuk dilanjutkan. 
Perolehan hasil dari kegiatan penelitian pada siklus II ini terbukti telah menunjukkan bahwa kemampuan siswa dalam mengikuti pelajaran sudah cukup baik. Ini terbukti dari ratarata nilai siswa mencapai 76,25 dengan ketuntasan belajar 91,66\%. Hasil ini menunjukkan bahwa Model Pembelajaran Tipe Cooperative Integrated Reading and Compotition (CIRC) telah berhasil meningkatkan kemampuan siswa menempa ilmu sesuai harapan. Model Pembelajaran Tipe Cooperative Integrated Reading and Compotition (CIRC) merupakan model yang cocok bagi siswa apabila guru menginginkan mereka memiliki kemampuan melakukan analisis, sintesis, berargumentasi, mengeluarkan pendapat secara lugas. Model Pembelajaran Tipe Cooperative Integrated Reading and Compotition (CIRC) mampu memupuk kemampuan intelektual siswa, mendorong siswa untuk mampu menemukan sendiri, menempatkan siswa pada posisi sentral dan mengupayakan agar siswa mampu belajar lewat penemuan agar materi yang dipelajari dapat diingiat lebih lama.

Hasil penelitian ini ternyata telah memberi efek utama bahwa model yang diterapkan dalam proses pembelajaran berpengaruh secara signifikan terhadap prestasi belajar siswa. Temuan ini membuktikan bahwa guru sudah tepat memilih metode dalam melaksanakan proses pembelajaran karena pemilihan metode merupakan hal yang tidak boleh dikesampingkan. Hal ini sejalan pula dengan temuan-temuan peneliti lain seperti yang dilakukan oleh Inten (2004) dan Puger (2004) yang pada dasarnya menyatakan bahwa metode pembelajaran yang diterapkan berpengaruh terhadap prestasi belajar siswa.

Upaya maksimal dalam melaksanakan pembelajaran pada siklus II dengan memperbaiki semua kelemahan-kelemahan sebelumnya telah mampu membuat peningkatan pemahaman dan keilmuan peserta didik. Dari nilai yang diperoleh siswa, 3 orang siswa memperoleh nilai sesuai KKM dan 2 siswa memperoleh nilai rendah. Atas dasar perolehan data dalam bentuk nilai tersebut dapat diyakini bahwa prestasi belajar siswa dapat ditingkatkan dengan penggunaan Model Pembelajaran Tipe Cooperative Integrated Reading and Compotition (CIRC).

Melihat perbandingan nilai awal, nilai siklus I dan nilai siklus II, terjadi kenaikan yang signifikan, yaitu dari rata-rata nilai awal adalah 58,33 naik di siklus I menjadi 63,54 dan di siklus II naik menjadi 76,25. Kenaikan ini tidak bisa dipandang sebelah mata karena kenaikan nilai ini adalah dari upaya-upaya yang maksimal yang dilaksanakan peneliti demi peningkatan mutu pendidikan dan kemajuan pendidikan khususnya di SD Negeri 4 Tulikup. Semua hasil yang diperoleh dari awal, siklus I dan siklus II digambarkan dalam bentuk Tabel dan grafik seperti berikut.

Tabel 1. Tabel Data Hasil Belajar Siswa kelas III SD Negeri 4 Tulikup

\begin{tabular}{lllll}
\hline DATA & AWAL & SIKLUS I & SIKLUS II & VARIABEL \\
\hline Skor Nilai & 1400 & 1525 & 1830 & Hasil Belajar IPS \\
Rata Rata Kelas & 58,33 & 63,54 & 76,25 & Dengan \\
Persentase Ketuntasan & $45,83 \%$ & $62,50 \%$ & $91,66 \%$ & KKM $=65$ \\
\hline
\end{tabular}

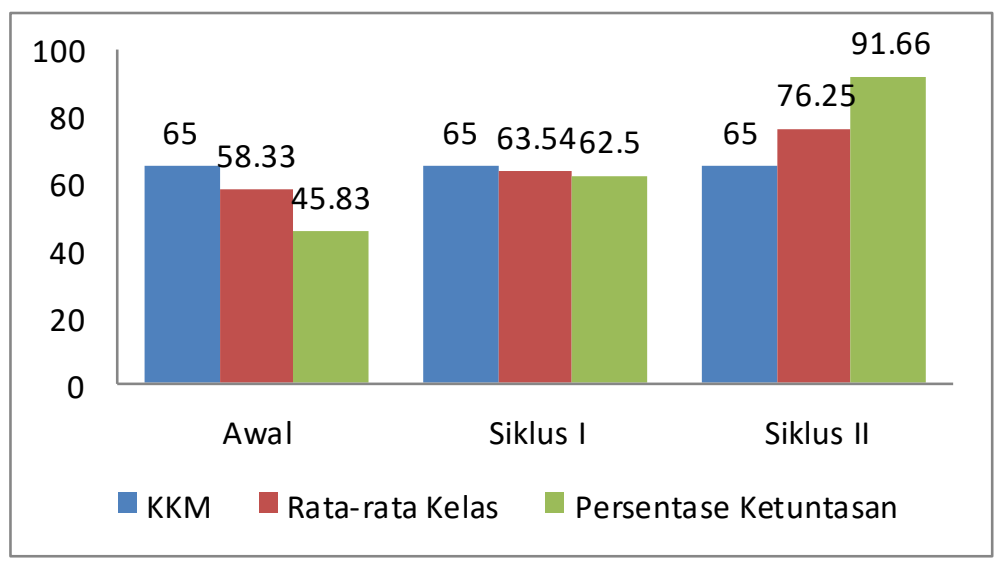

Gambar 2. Grafik Histogram Hasil Belajar IPS siswa kelas III semester II

Hasil penelitian ini sesuai dengan hasil penelitian yang dilakukan oleh Irawadi (2015) dengan judul Penerapan Model Pembelajaran Cooperative Integrated Reading and Compotition 
(CIRC) Untuk Meningkatkan Hasil Belajar Siswa Dalam Menulis Karya IImiah di Kelas XII AP I Smk Negeri 1 Seririt. Hasil penelitiannya menunjukkan bahwa, (1) langkah-langkah pembelajaran yang tepat dalam penelitian ini dititikberatkan pada tiga hal, yaitu pemberian wacana yang sesuai dengan jumlah masing-masing anggota kelompok, pemberian tema wacana yang dekat dengan lingkungan siswa, dan mengajak siswa menganalisis contoh proposal secara konkret; (2) penerapan model pembelajaran Cooperative Integrated Reading and Compotition (CIRC) dapat meningkatkan hasil belajar menulis karya ilmiah siswa. Hal ini dapat dilihat dalam perbandingan skor rata-rata klasikal, yakni pada pratindakan skor rata-rata klasikal 68,2 (cukup), siklus I memperoleh skor rata-rata klasikal 75,7 (baik), sedangkan pada siklus II nilai rata-rata klasikal siswa menjadi 82,2 (baik); (3) siswa memberikan respons sangat setuju terhadap penerapan model pembelajaran Cooperative Integrated Reading and Compotition (CIRC) dalam pembelajaran menulis karya ilmiah yakni dengan skor 45,3. Hasil penelitian ini juga menunjukkan bahwa ada peningkatan aktivitas guru dan aktivitas siswa dalam pembelajaran menulis karya ilmiah dengan menggunakan model pembelajaran Cooperative Integrated Reading and Compotition (CIRC). Peneliti menyarankan agar hasil penelitian ini dapat diterapkan oleh guru bahasa Indonesia untuk meningkatkan hasil belajar siswa dalam menulis karya ilmiah

\section{Simpulan dan Saran}

Simpulan yang dapat disampaikan berdasarkan semua hasil analisis data yang telah dilakukan dengan melihat hubungan rumusan masalah, tujuan penelitian, hipotesis tindakan dan semua hasil pembahasan adalah sebagai berikut: 1) Fokus pembahasan dari penelitian ini adalah untuk membuktikan apakah Model Pembelajaran Tipe Cooperative Integrated Reading and Compotition (CIRC) dapat meningkatkan prestasi belajar siswa kelas III SD Negeri 4 Tulikup. Dari hasi analisis yang telah dilakukan yang dilanjutkan dengan pembahasan dapat disampaikan bahwa peningkatan hasil belajar telah dapat diupayakan. Dari data awal yang rata-rata baru mencapai 58,33 dan jauh dari kriteria ketuntasan minimal pada mata pelajaran ini, pada siklus I sudah dapat ditingkatkan menjadi 63,54 dan pada siklus II sudah mencapai rata-rata 76,25 Siswa yang pada awalnya kemampuannya masih sangat rendah dimana hanya ada 11 yang tuntas, pada siklus I sudah dapat ditingkatkan yaitu ada 15 siswa yang sudah tuntas dan pada siklus II sudah 22 yang tuntas. Dari hasil awal ada 13 siswa yang harus diremidi sedangkan pada siklus II hanya 2 siswa yang mesti diremidi. 2) Dari uraian fakta-fakta di atas yang dibarengi dengan penyajian data hasil observasi baik siklus I maupun siklus II yang disampaikan pada Bab IV telah dapat dibuktikan bahwa Model Pembelajaran Tipe Cooperative Integrated Reading and Compotition (CIRC) dapat meningkatkan kemampuan siswa dalam belajar. Dengan hasil tersebut dapat dibuktikan bahwa rumusan masalah dan tujuan penelitian telah tercapai dan hipotesis yang diajukan sudah dapat diterima.

\section{Daftar Pustaka}

Aprilianty, Evie, Yani Kusmarni, Farida Sarimaya. 2016. Penerapan Model Pembelajaran Kooperatif Tipe Cooperative Integrated Reading Andcomposition (CIRC) untuk Meningkatkan Kemampuan Pemecahan Masalah Siswa. Factum Volume 5, Nomor 2, Hal. 187-202. Tersedia Pada: http://jurnal.upi.edu/file/EVIE_APRILIANTY,_YK_FS.pdf.

Arikunto, Suharsimi; Suhardjono; Supardi. 2006. Penelitian Tindakan Kelas. Jakarta: PT Bumi Aksara.

Ariyandika, Noviani, Rohana, Jayanti. 2017. Pengaruh Model Pembelajaran Kooperatif Tipe Cooperative Integrated Reading and Composition (CIRC) terhadap Kemampuan Pemecahan Masalah Matematis Siswa di SMP Negeri 22 Palembang. Nabla Dewantara: Jurnal Pendidikan Matematika Vol. 2 No. 1 Hal. 40-51. Tersedia Pada: http://www.ejournal.unitaspalembang.ac.id/index.php/nabla/article/view/17/17.

Badan Standar Nasional Pendidikan. 2007. Peraturan Menteri Pendidikan Nasional Republik Indonesia Nomor 41 Tahun 2007. Jakarta: BSNP.

Basrowi dan Sukidin. 2002. Metode Penelitian Kualitatif Perspektif Mikro. Surabaya. Insan Cendikia. 
Depdiknas. 2002. Ringkasan Kegiatan Belajar Mengajar. Jakarta: Depdiknas.

Depdiknas. 2010. Pedoman Pengembangan Program Pembelajaran di Taman Kanak-Kanak. Jakarta: Direktorat Pembinaan TK dan SD, Dirjen Pendidikan Dasar dan Menengah.

Depdiknas. 2010. Peraturan Menteri Pendidikan Nasional Republik Indonesia Nomor 58 Tahun 2009 tentang Standar Pendidikan Anak Usia Dini (PAUD). Jakarta: Direktorat Jendral Manajemen Pendidikan Dasar dan Menengah Direktorat Pembinaan TK dan SD.

Depdiknas. 2010. Perkembangan Anak Usia Dini. Jakarta: Direktorat Pembinaan TK dan SD, Dirjen Pendidikan Dasar dan Menengah.

Depdiknas. 2011. Membimbing Guru dalam Penelitian Tindakan Kelas. Jakarta: Pusat Pengembangan Tenaga Kependidikan Badan Pengembangan Sumber Daya Manusia Pendidikan dan Menjaminan Mutu Pendidikan.

Depdiknas. 2011. Petunjuk Teknis Penyelenggaraan Kelompok Bermain. Jakarta: Direktorat Pembinaan Pendidikan Anak Usia Dini Direktorat Jendral Pendidikan Anak Usia Dini, Nonformal dan Informal.

Depdiknas. 2011. Petunjuk Teknis Penyelenggaraan Taman Kanak-Kanak. Jakarta: Direktorat Pembinaan Pendidikan Anak Usia Dini Direktorat Jendral Pendidikan Anak Usia Dini, Nonformal dan Informal.

Fridani, Lara, dkk. 2009. Evaluasi Perkembangan Anak Usia Dini. Jakarta: Universitas Terbuka.

Ilham, Mhd. Jasri, Muakibatul Hasanah, Yuni Pratiwi. 2016. Pengaruh Model Pembelajaran Kooperatif Tipe Cooperative Integrated Reading And Composition (CIRC) Bermuatan Nilai Karakter terhadap Kemampuan Menulis Cerpen Siswa Kelas VII. Jurnal Pendidikan Humaniora Vol. 4 No. 3 Hal 121-131. Tersedia Pada: http://journal.um.ac.id/index.php/jph.

Irawadi, Made Hela. 2015. Penerapan Model Pembelajaran Cooperative Integrated Reading and Compotition (CIRC) Untuk Meningkatkan Hasil Belajar Siswa Dalam Menulis Karya IImiah di Kelas XII AP I Smk Negeri 1 Seririt. E-Jurnal Pendidikan dan Sastra Indonesia Undiksha Volume 3 Nomor 1.

Jenisa, Kintan, Asri Lubis. 2016. Penerapan Model Pembelajaran Cooperative Integrated Reading and Composition (CIRC) untuk Meningkatkan Motivasi dan Hasil Belajar Konstruksi Bangunan Siswa Kelas X TGB SMK Negeri 1 Lubuk Pakam. Jurnal Education Buuilding Vol. 2 No. 1 Hal. 77-86. Tersedia Pada: https://jurnal.unimed.ac.id/2012/index.php/eb/article/view/3850/0.

Martinis Yamin dan Jamila Sabri Sanan. 2013. Panduan PAUD. Ciputan : Gaung Persada Press Group.

Sukiastini, I G. A. N. K., I W. Sadia, I W. Suastra. 2013. Pengaruh Model Pembelajaran Cooperative Integrated Reading and Composition terhadap Kemampuan Pemecahan Masalah dan Berpikir Kreatif. e-Journal Program Pascasarjana Universitas Pendidikan Ganesha Program Studi IPA Vol. 3. Tersedia Pada: http://oldpasca.undiksha.ac.id/ejournal/index.php/jurnal_ipa/article/view/760. 